КУРИЛЮК Ю.Б.

\title{
ДЕРЖАВНА ПРИКОРДОННА СЛУЖБА УКРАЇНИ В СИСТЕМІ ОРГАНІВ ОХОРОНИ ПРАВОПОРЯДКУ
}

У статті на основі аналізу існуючих теоретичних поглядів і законодавчих конструкцій щодо правового статусу Державної прикордонної служби України в системи органів охорони правопорядку надано авторський підхід до розв'язання цієї проблеми. Зазначено, що в умовах останніх суспільно-політичних подій в Україні стабільний розвиток нашої держави тісно пов'язаний із безпекою ії кордону, а тому значної актуальності та важливості набувають дослідження проблем організації і правового регулювання таких спеціальних державних інституцій як Державна прикордонна служба України.

Встановлено, що натепер ця інституція має своє спеціальне призначення - забезпечення безпеки державного кордону України й охорони суверенних прав держави у її виключній (морській) економічній і прилеглій зонах. У цій сфері діяльності Державна прикордонна служба України впливає на ті події, прояви та явища, які несуть велику суспільну шкоду й потенційну загрозу окремим інтересам людини, суспільства та української держави.

Визначено, що чинне законодавство України визначає дуалістичну інституційну форму Державної прикордонної служби України як правоохоронного органу спеціального призначення та як військового формування. При цьому автор дотримується позиції, відповідно до якої широке трактування компетенції правоохоронних органів вимагає перегляду теперішнього статусу Державної прикордонної служби України та визнання її на законодавчому рівні органом охорони правопорядку. Така інституційна форма дасть змогу визначити, що у своєму функціоналі цей орган охоплює завдання як правоохоронного органу, так і військового формування.

Як підсумок зазначається, що Державна прикордонна служба України є органом охорони правопорядку зі специфічною виключно для неї сферою діяльності - забезпечення безпеки державного кордону України й охорони суверенних прав держави у іiі виключній (морській) економічній і прилеглій зонах.

Ключові слова: прикордонна служба, органи охорони правопорядку, правоохоронні органи.

Based on the analysis of the existing theoretical views and legislative norms regarding the legal status of the State Border Guard Service of Ukraine in the system of legal order protection agencies, the author's approach to solving this problem is given in the article. It is noted that under recent socio-political events in Ukraine, the stable development of our country is closely linked with the security of its border, and therefore researches of problems of organization and legal regulation of such special state institutions as the State Border Guard Service of Ukraine gain essential relevance and importance.

It is established that nowadays this institution has its special purpose that is ensuring the security of the state border of Ukraine and the protection of the sovereign rights of the State in its exclusive (maritime) economic and adjacent zones. In this area of activity, the State Border Guard Service of Ukraine influences those events, manifestations and phenomena that bear great public harm and potential threat to specific interests of an individual, society and the Ukrainian State. It is determined that the current legislation of Ukraine defines the dualistic institutional form of the State Border Guard Service of Ukraine as a special-purpose law enforcement agency and as a military body.

( С КУРИЛЮК Ю.Б. - кандидат юридичних наук, начальник управління адміністративної юрисдикції (Адміністрація Державної прикордонної служби України) 
At the same time, the author adheres to the position according to which the current broad interpretation of the competence of law enforcement agencies requires reviewing the current status of the State Border Guard Service of Ukraine and recognizing it at the legislative level as a legal order protection agency. This institutional form will enable to determine that in its functionality the agency covers the tasks of both law enforcement agency and military body.

As a result, it is noted that the State Border Guard Service of Ukraine is a legal order protection agency with a specific for this agency field of activity that is ensuring the security of the state border of Ukraine and protection of the sovereign rights of the State in its exclusive (maritime) economic and adjacent zones.

Key words: border guard service, legal order protection agencies, law enforcement agencies.

Вступ. Останні суспільно-політичні події в Україні вказують на те, що стабільний розвиток нашої держави тісно пов'язаний із безпекою її кордону. Практика показує, що більшість загроз національним інтересам України формуються та має передумови до зародження саме в межах прикордонних територій. Звідси вони розповсюджуються через державний кордон, втягуючи в свою систему або пособництво місцеве населення. Злочинні групи на державному кордоні у процесі своєї діяльності вдаються до насилля, відмивають величезні суми грошей, підкуповують посадових осіб, а також завдають шкоди та загрожують економічній і фінансовій системі держави.

Саме тому розбудова і розвиток України як правової держави невід'ємно пов'язана з належною організацією і функціонуванням системи інституцій, покликаних забезпечити правопорядок в усіх сферах суспільних відносин. Ефективна діяльність цих державних органів $є$ необхідною умовою захисту конституційного ладу, дотримання прав і свобод людини, а також забезпечення законності та правопорядку. Невідповідність організаційного та функціонального аспектів існування органів охорони правопорядку України зростаючим потребам суспільства та загальновизнаним міжнародним демократичним стандартам, як справедливо зауважила В.О. Боняк, не сприяє успішній реалізації національних інтересів і стабільності розвитку держави [1, с. 37].

За таких умов значної актуальності та важливості набувають дослідження проблем організації і правового регулювання профільного правоохоронного органу охорони правопорядку в цій сфері - Державної прикордонної служби України (далі - Держприкордонслужба).

Стан дослідження. Проблеми правового статусу Держприкордонслужби у сфері охорони правопорядку в різні роки досліджували О.Б. Ганьба, В.Л. Зьолка, О.В. Ільченко, І.Ф. Корж, І.П. Кушнір, Р.М. Ляшук, А.Ф. Мота, В.В. Половніков, А.М. Притула, Л.В. Серватюк, В.О. Хома, О.М. Царенко, С.I. Царенко та інші. Проте більшість дослідників присвячували свої праці здебільшого проблемам адміністративно-юрисдикційної діяльності, не розкриваючи змісту відомчої приналежності Держприкордонслужби до системи органів охорони правопорядку, а тому у цій статті автор має на меті вирішити деякі аспекти зазначеної проблеми.

Результати дослідження. Більшість науковців і практиків зазначають, що «головним суб'єктом забезпечення правопорядку у сфері охорони державного кордону є Держприкордонслужба» [2, с. 360]. Так само зазначає й О.В. Ільченко, що «правоохоронна діяльність Держприкордонслужби забезпечує правопорядок на державному кордоні, у прикордонні та у виключній (морській) економічній зоні України» [3, с. 11]. Так у чому ж полягає така впевненість авторів, адже на державному кордоні та в пунктах пропуску здійснюють свою діяльність безліч державних інституцій?

Конституцією України (ч. 3 ст. 17) безпосередньо та досить чітко закріплено вимогу щодо забезпечення прикордонної безпеки нашої держави, що випливає із законодавчої конструкції, яка зазначає, що «забезпечення державної безпеки і захисту державного кордону України покладається на відповідні військові формування та правоохоронні органи України, організація і порядок діяльності яких визначаються законом».

Крім того, зі змісту цього положення також чітко випливає розуміння того, що виконання обов'язку зі здійснення зазначеної діяльності відбувається виключно через військові формування і правоохоронні органи, проте вони мають бути відповідними для цього, тобто законодавчо й організаційно уповноваженими забезпечувати прикордонну безпеку України.

Як слушно зауважено В.В. Березенком, закономірно, що у наведеній статті 17 Конституції України частина третя викладена у логічній послідовності поряд з іншими частинами [4, с. 84]: 
- частина друга стосується обов’язку Збройних Сил України обороняти державу та захищати її територіальну цілісність, суверенітет і недоторканість;

- частина четверта стосується заборони застосування військових формувань для обмеження прав і свобод громадян із метою повалення конституційного ладу, усунення органів влади чи перешкоджання їх діяльності;

- частина п’ята стосується державних гарантій щодо забезпечення соціального захисту військовослужбовців, а також членів їхніх сімей;

- частина шоста стосується заборони створення і функціонування на території України будь-яких не передбачених законом збройних формувань;

- частина сьома стосується заборони розташування на території України іноземних військових баз.

Положення частини першої ст. 17 підкреслюють особливий (узагальнюючий) характер, важливість для всього українського народу, держави та її кордонів [4, с. 84].

«Захист державного кордону держави є невід’ємним складником загальнодержавної системи забезпечення національної безпеки України та передбачає скоординовану діяльність правоохоронних органів і військових формувань держави, порядок та організація діяльності яких визначаються виключно законом. Така діяльність провадиться в межах наданих цим інституціям повноважень шляхом вжиття комплексу політичних, організаційно-правових, прикордонних, міграційних, військових, економічних, розвідувальних, дипломатичних, контррозвідувальних, оперативно-розшукових, екологічних, санітарно-карантинних, природоохоронних, технічних та інших заходів» [5, с. 126].

Відповідно до абзацу 14 ч. 1 ст. 1 Закону України «Про оборону України» військовим формуванням визнається сукупність військових частин і з'єднань, органів їх управління, які утворюються відповідно до законодавства України та комплектуються військовослужбовцями, призначені для оборони України, захисту іiі територіальної цілісності, суверенітету, недоторканності, державної незалежності й національних інтересів [6].

Хоча Держприкордонслужбу згідно з профільним Законом України «Про Державну прикордонну службу України» [7] визнано правоохоронним органом спеціального призначення, їй також притаманні всі зазначені ознаки, що характеризують іiі і як військове формування. Також Стратегією національної безпеки України, ухваленою Указом Президента України від 26.05.2015 № 287/2015, на державному рівні бачення щодо інституційної форми Держприкордонслужби України в подальшій перспективі дещо інші та передбачають позбавлення ії статусу правоохоронного органу та наділити іï (в процесі подальшого реформування) статусом військового формування, який «має забезпечити ефективну реалізацію політики безпеки у сфері захисту та охорони державного кордону України, а також охорони суверенних прав України в ії виключній (морській) економічній зоні, у тому числі шляхом створення системи інтегрованого управління безпекою державного кордону України, удосконалення інформаційного, оперативного, технічного, фізичного складників, впровадження сучасних систем контролю, створення належно оснащених мобільних прикордонних загонів» [8].

У вітчизняній доктрині також існують особливі погляди щодо переосмислення статусу Держприкордонслужби. Зокрема, А.М. Притула пропонує визнати ії збройним формуванням спеціального призначення з правоохоронними функціями та із підпорядкування Головнокомандувачу Збройних Сил України [9, с. 49].

Змістовно схожої позиції дотримується І.Ф. Корж, зазначаючи, що «є необхідним законодавче корегування (уточнення) правового статусу Адміністрації Держприкордонслужби, трансформувавши іiї з нині існуючого статусу центрального органу виконавчої влади у центральний орган управління Держприкордонслужби за аналогією з правовим статусом Управління державної охорони та Служби безпеки України» [10]. Деякі ж дослідники дотримуються протилежної точки зору та пропонують «здійснити остаточний перехід Держприкордонслужби від військової структури до правоохоронного органу спеціального призначення» [11, с. 79]. Наразі ж Держприкордонслужба на рівні закону все ще залишається правоохоронним органом спеціального призначення.

Загалом в Україні є досить розгалужена система правоохоронних органів. Відповідно до чинного законодавства сюди належать органи прокуратури, внутрішніх справ, Служби безпеки, Держприкордонслужба [12, с. 89]. Однак цей перелік не є вичерпним, а законодавче визначення «правоохоронний орган», незважаючи на повсякчасне його зазначення у великій кількості нормативно-правових актів, відсутнє, як відсутній і відповідний перелік цих органів. Тому питання щодо приналежності певного органу до числа правоохоронних залишається досить спір- 
ним. В.Я. Тацій свого часу зазначив, що «поняття «правоохоронні органи» є одним із найбільш невизначених в українському правознавстві, внутрішньо суперечливим і надмірним за обсягом, а наука адміністративного права до правоохоронних органів відносить від 17 до 80 міністерств, відомств і організацій» [13].

Відповідно до ст. 2 Закону України «Про державний захист працівників суду і правоохоронних органів» [14] до правоохоронних органів належать органи прокуратури, Національної поліції, Служби безпеки, Військової служби правопорядку у Збройних Силах України, Національне антикорупційне бюро України, органи охорони державного кордону, органи доходів і зборів, органи і установи виконання покарань, слідчі ізолятори, органи державного фінансового контролю, рибоохорони, державної лісової охорони, інші органи, які здійснюють правозастосовні або правоохоронні функції.

В інших законодавчих актах розкриття правоохоронного органу здійснюється через окреслення характеру здійснюваних ним завдань. Так, відповідно до статті 1 Закону України «Про демократичний цивільний контроль над Воєнною організацією і правоохоронними органами держави» правоохоронними органами визнаються державні органи, що згідно із законодавством здійснюють правоохоронні чи правозастосовні функції. У ст. 1 вже не чинного Закону України «Про основи національної безпеки України» [15] визначалося, що правоохоронні органи - це органи державної влади, на які Конституцією та законами покладено здійснення правоохоронних функцій.

С.Я. Лихова свого часу визнала правоохоронні органи як «систему органів, уповноважених державою здійснювати нагляд і контроль за точним і неухильним додержанням законів усіма громадянами, посадовими особами, підприємствами, установами та організаціями, забезпечувати правопорядок, застосовувати засоби державного примусу до правопорушників» [16, с. 74].

Ю.С. Шемшученко вважає правоохоронні органи органами, «наділеними державою компетенцією щодо охорони врегульованих правом громадських відносин» [17, с. 513].

Ю.О. Загуменна визначила, що «правоохоронні органи є спеціально уповноваженими державними органами, які забезпечують (відповідно до своєї компетенції) дотримання та реалізацію прав і свобод громадян, законності та правопорядку із додержанням встановлених законом правил і процедур» [18, с. 149]. Більш того, є навіть такі науковці, які, крім державних інституцій, відносять до правоохоронних органів і громадські організації [16; 19], що є перебільшенням.

3 аналізу наведених прикладів розуміння правоохоронної діяльності постає питання щодо обгрунтованості віднесення до правоохоронних органів тих, які виконують правозастосовні чи контрольні функції, а також громадських організацій (наприклад, профспілки). Крім того, навряд чи, як справедливо зауважує М.В. Афанасьєва, «здійснення правоохоронної функції» як критерій виділення правоохоронних органів може бути результативно використаний, оскільки такі функції в тій або іншій мірі притаманні майже всім державним органам, насамперед органам виконавчої влади» [20, с. 224]. Більш того, як зауважує В.Я. Тацій, «у широкому тлумаченні під правоохоронними органами фактично можна розуміти всі органи виконавчої влади» [13].

Ситуація, яка склалася на законодавчому рівні щодо визначення відповідного понятійного апарату в системі правоохоронних органів, висвітлила проблему, що має комплексний характер. Розв'язання цієї проблеми вимагає формування оновленої правової основи як щодо організації, так і діяльності відповідних державних інституцій, уповноважених забезпечувати правопорядок у державі. У цьому контексті автор підтримує позицію М.В. Афанасьєвої щодо необхідності відмови (на законодавчому й правозастосовному рівнях) від терміну «правоохоронний орган» i здійснити поділ системи відповідних державних органів залежно від їх функціоналу та призначення, що й виступатиме критерієм для виокремлення їх певних класифікаційних груп: органи охорони правопорядку, а також контрольно-наглядові органи виконавчої влади, до яких, зокрема, можна віднести певні державні інспекції, основні повноваження яких спрямовані на здійснення контролю за дотриманням законодавства України у певній сфері державного управління, а правоохоронний складник для них не є основним, а тільки допоміжним [20, с. 225].

Зазначене стосується й Держприкордонслужби, адже сам законодавець визначив дуалістичну інституційну форму цього державного органу (правоохоронного органу та військового формування). Як зауважує А.М. Притула, Держприкордонслужба з урахуванням положень законів України «Про Державну прикордонну службу України» та «Про національну безпеку України» віднесена і до сил безпеки (сили безпеки - правоохоронні та розвідувальні органи, державні органи спеціального призначення з правоохоронними функціями, сили цивільного захисту та інші органи, на які Конституцією та законами України покладено функції із забезпечення національної безпеки України), а до сил оборони (сили оборони - Збройні Сили України, а також інші 
утворені відповідно до законів України військові формування, правоохоронні та розвідувальні органи, органи спеціального призначення з правоохоронними функціями, на які Конституцією та законами України покладено функції із забезпечення оборони держави) [9, с. 40-41].

На думку автора, закріплення на законодавчому рівні за Держприкордонслужбою статусу "органу охорони правопорядку» дасть змогу зрозуміти, що ця інституція у своєму функціоналі охоплює завдання як правоохоронного органу, так і військового формування.

На початку 2019 року набрав чинності схвалений 06.12.2018 Верховною Радою України Закон України № 2641-VIII «Про прилеглу зону України» [21], перехідними положеннями якого також внесено певні зміни до Закону України «Про Державну прикордонну службу України», які доповнили основні завдання прикордонного відомства, передбачені статтею 1, новим завданням - охорони суверенних прав України в ії прилеглій зоні.

Якщо раніше назва ст. 21 останнього звучала як «Застосування сили під час охорони державного кордону та суверенних прав Украӥни в ї̈ виключній (морській) економічній зоні», то після набрання чинності Законом України «Про прилеглу зону України» вона піддалася суттевим змінам та отримала таке формулювання «Застосування фізичної сили, спеціальних засобів, зброї та бойової техніки особовим складом Державної прикордонної служби Украӥни». Окрім цього, ст. 21 також отримала важливе змістовне корегування, результат якого слід розцінювати як додатковий аргумент на користь визнання Держприкордонслужби України органом охорони правопорядку, оскільки законом було закріплено додаткові та досить чіткі підстави для застосування зброї кораблів і катерів Морської охорони Держприкордонслужби України, у тому числі 3 попередженням і без нього.

Виходячи з положень ст. 1 Закону України «Про Державну прикордонну службу України» та ч. 6 ст. 18 Закону України «Про національну безпеку України» [22], а також враховуючи, що «правове регулювання та організація діяльності Держприкордонслужби мають свою специфіку, яка обумовлюється конституційними положеннями про те, що однією з головних функцій держави $є$ забезпечення захисту суверенітету, територіальної цілісності, недоторканності кордонів» [23, с. 270], натепер Держприкордонслужба має своє спеціальне призначення - забезпечення безпеки державного кордону України й охорони суверенних прав держави у її виключній (морській) економічній і прилеглій зонах.

Саме у вказаній сфері діяльності цей державний орган буде впливати на ті «події, прояви або явища, які несуть велику суспільну шкоду й потенційно загрожують не тільки окремим інтересам людини та суспільства, але й в окремих випадках нестимуть загрозу його нормальному існуванню взагалі», щодо яких веде мову В.І. Лазутко [24, с. 358-359] як про об'єкти службово-бойової діяльності відповідних органів охорони правопорядку.

Висновки. Проведений аналіз дає змогу зробити висновок про те, що Держприкордонслужба є органом охорони правопорядку зі специфічною виключно для неї сферою своєї діяльності - забезпечення безпеки державного кордону України й охорони суверенних прав держави у ії̈ виключній (морській) економічній і прилеглій зонах.

Перспективами подальших досліджень у цій сфері має стати визначення ознак, які дають змогу встановити приналежність відповідної державної інституції до системи органів охорони правопорядку, а також правового статусу кожної з цих інституцій та ролі у забезпеченні правопорядку за компетенцією.

\section{Список використаних джерел:}

1. Боняк О.В. Органи охорони правопорядку України: зміст поняття, його обсяг і різновиди. Науковий вісник Львівського державного університету внутрішніх справ. 2015. № 2. C. $37-48$.

2. Зьолка В.Л. Охорона національних інтересів України у прикордонній сфері (адміністративно-правовий аспект) : монографія. Хмельницький : НАДПСУ, 2015. 672 с.

3. Ільченко О.В. Організаційно-правові засади взаємодії органів внутрішніх справ та Державної прикордонної служби України в умовах євроінтеграції : автореф. дис. канд. юрид. наук: спец. 12.00.07. Київ, 2014. 19 с.

4. Березенко В.В. Правовий режим державного кордону України: конституційно-правові аспекти регулювання та захисту : дис. канд. юрид. наук: спец. 12.00.02. Київ, 2017. 235 с.

5. Конституція України. Науково-практичний коментар / редкол.: В.Я. Тацій (голова), О.В. Петришин (відп. секретар), Ю.Г. Барабаш та ін. 2-ге вид. перероб. і доп. Харків : Право, 2011. $1128 \mathrm{c}$. 
6. Про оборону України : Закон України від 06.12.1991 № 1932-XII. Відомості Верховної Ради Украӥни. 1992. № 9. Ст. 106.

7. Про Державну прикордонну службу України : Закон України від 03.04.2003 № 661-IV. Відомості Верховної Ради України. 2003. № 27. Ст. 208.

8. Про рішення Ради національної безпеки і оборони України від 6 травня 2015 року «Про Стратегію національної безпеки України» : Указ Президента України 26.05.2015 № 287/2015. Офіиійний вісник Президента Украӥни. 2015. № 13. Ст. 50.

9. Притула А.М. Теоретико-правові засади оперативно-службової діяльності Державної прикордонної служби України : монографія. Одеса : Фенікс, 2019. 332 с.

10. Корж I. Державна прикордонна служба України: правовий статус та місце в системі сектору безпеки і оборони. Вісник Національної академії Державної прикордонної служби України. Серія: Юридичні науки. 2017. Вип. 2. URL: http://nbuv.gov.ua/UJRN/vnadpcurn_2017_2_3.

11. Савенко I.M. Організаційно-правовий механізм державного управління прикордонною службою України : дис. канд. наук з держ. упр. Спец. 25.00.02. Львів, 2016. 205 с.

12. Курилюк Ю.Б. Відповідальність військовослужбовців за перевищення влади або службових повноважень: деякі законодавчі прогалини. Вісник прокуратури. 2015. № 2. С. 86-91.

13. Тацій В.Я. Доповідь Комісії з питань правоохоронної діяльності щодо визначення поняття та системи правоохоронних органів. URL: http://constituanta.blogspot.com/2013/02/ blog-post_2280.html.

14. Про державний захист працівників суду і правоохоронних органів : Закон України від 23.12.1993 № 3781-ХІІ. Відомості Верховної Ради України. 1994. № 11. Ст. 50.

15. Про основи національної безпеки України : Закон України від 19.06.2003 № 964-IV. Відомості Верховної Ради України. 2003. № 39. Ст. 351.

17. Лихова С. Про визначення поняття «правоохоронні органи». Радянське право. 1984. № 11. C. 74-76.

18. Юридичний словник-довідник / за ред. Ю.С. Шемшученка. К. : Феміна, 1996. 696 с.

18. Загуменна Ю.О. Правоохоронні органи: поняття, ознаки, функції, особливості діяльності. Право і безпека. 2010. № 3(35). С. 145-150.

19. Семенов В.М. Правоохранительные органы в СССР. Москва : Юрид. лит., 1990. 400 с.

20. Конституційне право України: прагматичний курс : навч. посіб. / за заг. ред. М.В. Афанасьєвої, А.А. Єзерова. Одеса : Юрид. літ., 2017. 256 с.

21. Про прилеглу зону України : Закон України від 06.12.2018 № 2641-VIII. Biдомості Верховної Ради України. 2019. № 3. Ст. 5.

22. Про національну безпеку України : Закон України від 21.06.2018 № 2469-VIII. Вiдомості Верховної Ради України. 2018. № 31. Ст. 5.

23. Ляшук Р.М. Діяльність відділів прикордонної служби Державної прикордонної служби України (адміністративно-правовий аспект) : монографія. Хмельницький : НАДПСУ, 2015. 386 с.

24. Лазутко B.I. Сили охорони правопорядку: проблемні питання визначення та характеристики. Форум права. 2012. № 3. С. 358-359. 